Original Research

\title{
Waist Circumference as a Predictor for Menstrual Cycle Disturbance Among College Student
}

\section{Ni Nyoman Trioka Rtamagustini, Bambang Purwanto and Hanifa Erlin Dharmayanti}

Faculty of Medicine, Universitas Airlangga, Surabaya, Indonesia

\begin{abstract}
Introduction: Menstrual cycle disturbance is the sign of a reproductive health problem, yet the cause tends to be multifactorial. This study aimed to analyze the risk factors of menstrual cycle disturbance which related to nutrition status among college students.
\end{abstract}

Methods: This was an observational analytical study with a cross-sectional approach. There were 59 participants taken as samples according to inclusion criteria using proportionate stratified random sampling. Data were analyzed with chi-square and multiple logistic regression test.

Results: Results found that $35.6 \%$ of participants experienced menstrual cycle disturbance. Bivariate analysis showed significant correlation between body fat percentage ( $p=0.038$, OR: 2.417) and waist circumference ( $p=0.003,0 R: 2.956)$ with menstrual cycle disturbance, otherwise no correlation found between Body Mass Index (BMI) $(p=0.052$, OR: 2.145), subcutaneous fat thickness $(p=1,0 R$ : 1.279), and total cholesterol levels $(p=1,0 R$ : 1.063) with menstrual cycle disturbance. Multiple logistic regression analysis showed that waist circumference became determinant factor among other variables predicting menstrual cycle disturbance in this study ( $\mathrm{p}=0.002,0 \mathrm{R}$ : 7.260).

Conclusion: Waist circumference and body fat percentage were both risk factors of menstrual cycle disturbance, yet waist circumference was found being a determinant predictor to predict menstrual cycle disturbance among college student. Female students may pay particular attention to their waist circumference for detection of reproductive health problem earlier, especially regarding menstruation cycle disturbance.

\section{ARTICLE HISTORY}

Received: May 17, 2018

Accepted: January 21, 2019

\section{KEYWORDS}

college student; menstruation cycle; waist circumference

\section{CONTACT}

Bambang Purwanto $\triangle$ bambangpurwanto@fk.unair.ac.id $\Xi$ Faculty of Medicine, Airlangga University, Surabaya, Indonesia

Cite this as: Rtamagustini, NNT., Purwanto, B., \& Dharmayanti, HE. (2018). Waist Circumference as a Predictor for Menstrual Cycle Disturbance Among College Student. Jurnal Ners, 13(2), 194-199. doi:http://dx.doi.org/10.20473/jn.v13i2.8335

\section{INTRODUCTION}

Menstrual cycle disturbance is a symptom of reproductive health and other health problems such as infertility, tumours, cancer, obesity, hyperinsulinemia, diabetes mellitus, and cardiovascular disease (Greenstein and Wood, 2010; Welch, 2011; Santoso, 2014). Generally, menstrual cycles tend to be irregular for several years after menarche then steadily regular at around 17-18 years old. Frequent problems arose as irregular menstrual cycle disorders were polymenorrhea (a cycle is shorter than 21 days), oligomenorrhea (a menstrual cycle is longer than 35 days), and amenorrhea (menstrual absence for more than 6 months) (Benson and Pernoll, 2008; Manuaba, et.al., 2010).
There were $38.4 \%$ cases of menstrual cycle disturbance for women aged around 16 years old reported in Sweden. Despite, the problem was also still occurred on $29.7 \%$ of 26 years old women (West, et al., 2014). While in another study, menstrual cycle disturbance was found not only experienced by women with underweight, overweight, and obesity nutrition status but also occurred in normal nutrition status (Rachmawati and Murbawani, 2015; Mustaqeem, et. al., 2015). It shows inconsistency regarding the correlation between nutrition status with menstrual cycle disturbance. Based on that fact, a preliminary study was conducted among college which showed that $30 \%$ out of 10 respondents experienced menstrual cycle disturbance. 
The causes of menstrual cycle disturbance are multifactorial. Commonly, it can be caused by a disruption in a hypothalamic-pituitary-ovarian axis which related to nutrition status, physical activity, stress, and some diseases including metabolic syndrome (Rakhmawati and Fithra, 2013; Rachmawati and Murbawani, 2015; Arum, 2015; Noviandari, 2016; Yani, 2016). Recently, adolescents are also vulnerable to type 2 diabetes mellitus and metabolic diseases. Basic Health research stated that $36.6 \%$ of the population aged around 15 years old and more had experienced abnormal Fasting Glucose Level (FG), 29.9\% had abnormal glucose tolerance, and 35.9\% had abnormal total cholesterol level (Departemen Kesehatan Republik Indonesia, 2013).

The varied risk factor of menstrual cycle disturbance might result from suboptimal prevention and management effort. Determining risk factors related to nutrition status may enhance selfprevention and management effort among individuals. Nutritional status can be identified by weight examination, body composition, and lipid profile. The research focused on menstrual cycle disturbance that related to nutrition status based on Body Mass Index (BMI), waist circumference, body fat percentage, subcutaneous fat thickness, and total cholesterol levels is relatively rare to be found. Therefore, this research might offer a solution as it attempted to analyse the risk factors of menstrual cycle disturbance based on nutritional status in the fertile female adolescent group

This study aimed to analyze the risk factors of irregular menstruation cycle related to nutrition status. Specifically, it purposed to analyze correlation between Body Massa Index (BMI), waist circumference, body fat percentage, subcutaneous fat thickness, and total blood cholesterol levels with menstrual cycle disturbance on college students.

\section{MATERIALS AND METHODS}

This research was an observational analytical research with a cross-sectional design. The population of this study were the female college of the undergraduate program who already experienced menarche, 19-21 years old, unmarried, and willing to be a research participant were included in this study. Otherwise, those who had primary amenorrhoea, secondary amenorrhoea due to hyperprolactinemia or internal genetic tumours such as myomas and cysts, were pregnant, breastfeeding, iatrogenic menopause, using hormonal contraceptives, drugs or supplements that affect the menstrual cycle, consumed alcohol, and active smoking was excluded. Anamnesis and abdominal examination through palpation were performed to eliminate the chance of having menstrual cycle disorder due to an organic disorder. The sample size was determined using hypothesis tests for two population proportion formulas (Lemeshow and Lwanga, 1990).Total participants of 59 colleges taken using proportionate stratified random sampling technique.The study was conducted during September 2017-April 2018. Independent variables of this study were BMI, waist circumference, body fat percentage, subcutaneous fat, and total cholesterol levels. Based on Indonesian Health Ministry Nutrition Guidelines, normal standard of BMI values was $(>18.5-<24.9) \mathrm{kg} / \mathrm{m} 2,(<$ $80 \mathrm{~cm})$ for waist circumference, $(>17.7 \%-<29.6 \%)$ for body fat percentage, $(<200 \mathrm{mg} / \mathrm{dl})$ for total cholesterol, and (14-21\%) for subcutaneous fat thickness. The dependent variable of this research was menstrual cycle disturbance, defined as the absence of menstruation for more than 3 cycle, shorter or longer periods of the menstrual cycle in 24-38 days of range for a year (4-5 times).

The subject was characterized on age, menarche, sleep duration, exercise, diet, anxiety stress, and menstrual profile. Data were collected using structured questionnaires and examining required measurements such as height, weight, waist circumference, body fat percentage, subcutaneous fat thickness, and capillary blood sampling for fasting total cholesterol test (approximately 12 hours-fasting). This study used Microtoise band to measure waist circumference, Tanita Scale Innerscan Body Composition Monitor and skinfold calliper to measure participants' nutritional state. Modified Anxiety Stress Scales 42 (Lovibond, 2011) was used to measure and categorize anxiety stress level of subjects into the low and normal level. Structured measurements form was used to collect menstrual profile data then categorize into normal and menstrual cycle disturbance.

Collected data were analyzed using IBM® Statistical Package for the Social Sciences (SPSS) Statistics 24 for univariate, bivariate, and multivariate analysis. Univariate analysis was performed to look into the characteristics of participants and the frequency distribution of each variable in this study. Bivariate analysis was performed using the chi-square test to identify correlation and collinearity between each independent variable with the dependent variable. Multivariate analysis was performed using multiple logistic regression test which required more than two variables being correlated to analyze and had chi-square test value of $>0.25$ with $\alpha=0.05$. This research has been approved ethically by the Ethics Committee of the Faculty of Medicine, Universitas Airlangga with letter number 336/EC/KEPK/FKUA/2017.

\section{RESULTS}

Characteristics of participants are described in Table 1. Participants with menstrual cycle disturbance (35.6\%) were found less than regular or normal menstrual cycle (64.4\%). Age distribution in this study ranged from 19 to 21 years old. Participants whose age at around 19 and 20 years old (35.6\% and $39.0 \%$ ) were found more than those who were 21 years old (25.4\%). Age of menarche ranged from 10 
Table 1. The Distribution for Characteristics of Participants $(n=59)$

\begin{tabular}{cccc}
\hline Characteristics & Category & Frequency (n) & Percentage (\%) \\
\hline Age & 19 years old & 21 & 35.6 \\
& 20 years old & 23 & 39.0 \\
Menarche & 21 years old & 15 & 25.4 \\
& 10 years old & 2 & 3.4 \\
& 11 years old & 14 & 23.7 \\
& 12 years old & 15 & 25.4 \\
& 13 years old & 12 & 20.3 \\
Sleep duration & 14 years old & 16 & 27.1 \\
& $<8$ hours/day & 50 & 84.7 \\
Exercise & $\geq 8$ hours/day & 9 & 15.3 \\
& Yes & 7 & 88.1 \\
Vegetarian & No & 52 & 6.8 \\
& Yes & 4 & 93.2 \\
Soybean consumption & No & 55 & 93.2 \\
Stress & Yes & 55 & 6.8 \\
& No & 4 & 61.0 \\
Menstruation cycle & Normal & 36 & 30.5 \\
& Low & 18 & 8.5 \\
\end{tabular}

Table 2. The result of Bivariate Analysis Using Chi-Square $(n=59)$

\begin{tabular}{|c|c|c|c|c|c|c|c|c|}
\hline \multirow[t]{3}{*}{ Variable } & \multicolumn{4}{|c|}{ Menstruation cycle } & \multicolumn{2}{|c|}{ Total } & \multirow[t]{3}{*}{ p-value } & \multirow{3}{*}{$\begin{array}{l}\text { Odds } \\
\text { Ratio }\end{array}$} \\
\hline & \multicolumn{2}{|c|}{ Irregular } & \multicolumn{2}{|c|}{ Regular } & \multirow[b]{2}{*}{ (n) } & \multirow[b]{2}{*}{$(\%)$} & & \\
\hline & (n) & $(\%)$ & (n) & $(\%)$ & & & & \\
\hline \multicolumn{9}{|l|}{ BMI } \\
\hline Abnormal & 11 & 52.4 & 9 & 23.7 & 20 & 33.9 & 0.052 & 2.145 \\
\hline Normal & 10 & 47.6 & 29 & 76.3 & 39 & 66.1 & & \\
\hline \multicolumn{9}{|c|}{ Waist Circumference } \\
\hline Abnormal & 11 & 52.4 & 5 & 13.2 & 16 & 27.1 & 0.003 & 2.956 \\
\hline Normal & 10 & 47.6 & 33 & 86.8 & 43 & 72.9 & & \\
\hline \multicolumn{9}{|c|}{ Body Fat Percentage } \\
\hline Abnormal & 15 & 71.4 & 15 & 39.5 & 30 & 50.8 & 0.038 & 2.417 \\
\hline Normal & 6 & 28.6 & 23 & 60.5 & 29 & 49.2 & & \\
\hline \multicolumn{9}{|c|}{ Subcutaneous Fat Thickness } \\
\hline Abnormal & 19 & 90.5 & 33 & 86.8 & 52 & 88.1 & 1 & 1.279 \\
\hline Normal & 2 & 9.5 & 5 & 13.2 & 7 & 11.9 & & \\
\hline \multicolumn{9}{|c|}{ Total Cholesterol Levels } \\
\hline Abnormal & 3 & 14,3 & 5 & 13.2 & 8 & 13.6 & 1 & 1.063 \\
\hline Normal & 18 & 85.7 & 33 & 86.8 & 51 & 86.4 & & \\
\hline
\end{tabular}

Table 3. The result of First Step Multiple Regression Logistic Analysis

\begin{tabular}{cccccc}
\hline Variable & B & Sig & OR & \multicolumn{2}{c}{ CI 95\% } \\
\cline { 4 - 6 } & & & & Lower & Upper \\
\hline Body Fat Percentage & 0.462 & 0.543 & 1.587 & 0.359 & 7.021 \\
BMI & 0.794 & 0.221 & 2.211 & 0.620 & 7.879 \\
Waist Circumference & 1.426 & 0.088 & 4.161 & 0.810 & 21.368 \\
Constant & -1.569 & 0.002 & 0.208 & & \\
\hline
\end{tabular}

Table 4. The result of Third Step Model Regression Logistic Analysis

\begin{tabular}{cccccc}
\hline Variable & B & Sig & OR & \multicolumn{2}{c}{ CI 95\% } \\
\cline { 4 - 6 } & & & & Lower & Upper \\
\hline Waist Circumference & 1.982 & 0.002 & 7.260 & 2.035 & 25.904 \\
Constant & -1.194 & 0.001 & 0.303 & & \\
\hline
\end{tabular}

years old until 14 years old. Majority of participants complained having bad sleep duration which was less than 8 hours/day (84.7\%) and did not frequently exercise per week (88.1\%). Most of the participants had a normal level of stress $(61.0 \%)$, with only $(8.5 \%)$ participants mentioned having a moderate level of stress. Most of the participants had a non-vegetarian diet (93.2\%) and consumed soybean $(93.2 \%)$.

The result of chi-square analysis could be seen in Table 2. The correlation was found on both analysis between waist circumference with menstrual cycle 
disturbance, and between body fat percentage with menstrual cycle disturbance with a p-value $<0.05$ $(p=0.003$ and $p=0.038)$. Whereas different results were found on the correlation between BMI, subcutaneous fat thickness, and total cholesterol levels with menstrual cycle disturbance ( $\mathrm{p}$-value > $0.05)$. An odds ratio value of all variables were at more than one. An odds ratio value of 2.956 for correlation between waist circumference with menstrual cycle disturbance indicated college students with $>80 \mathrm{~cm}$ waist circumference had 2.956 times riskier than those with normal waist circumference.

Multiple logistic regression was performed to determine the predominant factor for menstrual cycle disturbance. The result could be seen on table 3 and 4 . There were three variables as candidates of menstrual cycle disturbance predictor, as in body mass index, waist circumference, and body fat percentage. A variable with the greatest significant p-value is eliminated gradually until we obtained a model with significant value below to 0.05 . The multiple regression model analysis resulted in only waist circumference as a determinat risk factor. It suggested that waist circumference as the only determinant risk factor of menstrual cycle disturbance on this study. Based on multiple logistic regression with $\mathrm{OR}$ value of 7.2 , it could be suggested that college students who had abnormal waist circumference would be 7.2 times riskier to have menstrual cycle disturbance than those with normal waist circumference.

\section{DISCUSSION}

Five independent variables were analysed as predictor candidates for menstrual cycle disturbance. There were three of five variables correlated to menstrual cycle disturbance, i.e. body mass index, waist circumference and body fat percentage.The previous study has exposed a significant correlation between irregular menstrual cycle and waist circumference. It assumed that waist circumference was associated with menstrual cycle disturbance (Song, et. al., 2016). Another previous study had a similar result, of which assumed that oligomenorrhea was correlated with waist circumference (Seif, Diamond, and Nickkhoo-Amiry, 2014).

Abnormal waist circumference indicates that there is an accumulation of fat stored exceeding its normal part in the abdomen. It is also called central obesity or central adiposity. Therefore, central obesity occurs when there is an accumulation of fat around the abdomen region particularly at the abdomen cavity in the outer wall of the intestine (Cahyono, 2008).

Obesity is determined using such BMI measurement which calculates weight and height, body fat percentage, subcutaneous fat thickness and waist circumference. Measurement of waist circumference was relatively easier to do, but it was proved more accurate to describe central obesity than other variables (National Health Service, 2016). Our findings confirmed that waist circumference was the only variable in the logistic regression model to predict menstrual cycle disturbance. In addition, obesity also as a risk factor of hormonal abnormality which correlates to a reproductive problems such as infertility, PCOs, and menstrual irregularity. Obesity was known as the risk of chronic anovulation (Seif, Diamond, and Nickkhoo-Amiry, 2014).

Due to obesity, chronic anovulation occurs in three ways as in high peripheral aromatization of androgens, low level of Sex Hormone Binding Globulin (SHBG) production, and insulin resistance (Fritz and Speroff, 2011). High peripheral aromatization of androgens leads to chronically accelerated estrogen concentration. Androgen also functions as estrogen precursor. Therefore, estrogen is not only derived from the ovary but also from its precursor. While a low level of SHBG production in the liver may increase circulating concentrations of free testosterone and estradiol in the blood. As for insulin resistance, it results in androgen production in the ovarian stroma. Higher concentration of local androgen might disrupt the development of follicle. Disturbances in the follicle process can cause chronic anovulation. Particular weight loss program decreases blood insulin and androgen levels, it also restores the ovulatory function of menstrual cycles (Fritz and Speroff, 2011).

The factors affecting waist circumference are age, physical activity, energy intake, genetic, alcohol, and stress (Ranggadwipa and Murbawani, 2014; Rasdini, 2016). Physical activity may decrease when someone gets older. Excessive diet and lack of physical activity impair on increasing the waist circumference. Excessive calories are found in fast foods, processed meats, margarine, canned vegetables, and recycled cooking oil.The type of foods that may trigger glucose production in large quantities.

The pancreas has a function to secrete insulin and convert it into the energy that is essential for the cell metabolism. Improper catabolism activity result in disruption of that function which leads to excessive fat stored in more parts of the body and eventually also leads to central obesity. While an individual may have a tendency to have fat accumulation in the abdomen genetically, but it may be avoidable if radical weight gain did not occur. On the other hand, alcohol consumption may result in decreasing fat burning efficiency. Fat accumulation will occur if there is no lifestyle changing by reducing alcohol. At last, stress and lack of sleep can increase production of the cortisol hormone which disposes fat accumulating in the stomach. Therefore, avoiding those risk factors may be beneficial to maintain normal waist circumference.

Fats disturb hormonal secretion level and balance that regulate menstruation cycle by shaping, converting, and storing reproductive hormones. Excessive fat can cause blood vessel hyperplasia. The blood vessel will be suppressed by fat tissue 
resulting in a disruption on blood circulation in the reproductive system becomes (Rachmawati and Murbawani, 2015). On the other hand, massive weight loss and underweight condition decrease gonadotropin hormones that secrete LH and FSH. It may also decrease the estrogen level and stimulate anovulatory condition which leads to the menstrual cycle disturbance (Hidayah, Rafliudin, and Ronny, 2016).

Androgen excess in women with PCOS and obesity may be accompanied by abnormal metabolic conditions, which is characterized by increasing abdominal fat and decreasing lipolysis in subcutaneous fat (Kim et. al., 2014). Lifestyle management by regulating considerable physical activity, reducing fast-food consumption, healthy eating habits, keeping the ideal BMI are few ways to improve reproductive health, particularly in maintaining regular menstrual cycle (Jena, Panda, Mishra, and Narahari, 2017).

Previous studies suggested that cholesterol has no correlation with menstrual irregularity. Women with a history of menstrual cycle disorders had a higher risk to suffer from diabetes mellitus (Dovom, et. al., 2016). Similarly, this study showed that total cholesterol levels did not have a significant relationship with menstrual irregularity. Normally, menstrual irregularity often occurs at the beginning of the menarche. Despite menstrual cycle disorders are likely to occur in upcoming years, metabolic disorders screening may become beneficial for prevention efforts.

\section{CONCLUSION}

This study showed a correlation between waist circumference and body fat percentage with menstrual cycle disturbance. Otherwise, no correlation was found between BMI, subcutaneous fat, and total cholesterol level with menstrual cycle disturbance. While college student with abnormal waist circumference and body fat percentage were shown being at more risk to develop menstrual cycle disturbance. Waist circumference was proven as a predictor to determine menstrual cycle disturbance among college student. Future investigation is needed to explore more some variables which involve in menstrual cycle disturbance mechanism related to obesity such as free radicals, proinflammatory cytokine and hormones.

\section{ACKNOWLEDGMENT}

We thank to Midwifery Department of the Faculty of Medicine, Universitas Airlangga, for the study administration.

\section{REFERENCES}

Arum, V. R. (2015). Hubungan Status Gizi dengan Kejadian Oligomenore pada Sisiwi di SMK PERINTIS 29 UNGARAN. Semarang: DIV Kebidanan STIKES Ngudi Waluyo Ungaran.
Benson, R. C., \& Pernoll, M. L. (2008). Buku Saku Obstetri dan Ginekologi. Jakarta: EGC.

Cahyono, S. B. (2008). Gaya Hidup dan Penyakit Modern. Yogyakarta: Kanisius.

Departemen Kesehatan Republik Indonesia. (2013). Riset Kesehatan Dasar 2013. [online] Available at: www.depkes.go.id/resources/download/general /Hasil\%20Riskesdas\%202013.pdf. (Accessed: September 2, 2017).

Dovom, R. M., Tehrani, R. F., Djalalinia, S., Cheragi, L., Gandavani, S. B., \& Azizi, f. (2016). Menstrual Cycle Irregularity and Metabolic Disorders: a Population-Based Prospective Study. Plos One, 11(12), e0168402. doi:10.1371/journal.pone.0168402.

Fritz, M. A., \& Speroff, L. (2011). Clinical Gynecology Endocrinology and Infertility (8th ed.). USA: Lippincott Williams \& Wilkins.

Greenstein, B., \& Wood, D. F. (2010). At a Glance Sistem Endokrin (2nd ed.). Jakarta: Erlangga.

Hidayah, N., Rafliudin, M. Z., \& Ronny, A. (2016). Hubungan Status Gizi, Asupan Gizi dan Aktifitas Fisik dengan Siklus Menstruasi Remaja Putri Pondok Pesantren Salafiyah Kauman Kabupaten Pemalang Tahun 2016. Jurnal Kesehatan Masyarakat, IV(4), 537-544.

Jena, P., Panda, J., Mishra, A., \& Narahari, A. (2017). Menstrual Pattern and Body Mass Index in Adolescent School Girls; a cross-sectional study. Global Journal for Research and Analysis, VI(6), 29-31. doi:10.1186/s12905-016-0354-y.

Kim, M.-J., Lim, N. K., Choi, Y. M., Kim, J. J., Hwang, K. R., Chae, S. J., \& Kim, T. (2014). Prevalence of metabolic syndrome is higher among non-obese PCOS women with hyperandrogenism and menstrual irregularity in Korea. Plos One, IX(6), e99252. doi.org/10.1371/journal.pone.0099252.

Lemeshow, S., \& Lwanga, S. K. (1990). Adequacy of Sample Size in Health Studies. Singapore: John Wiley \& Sons on behalf of World Health Organization.

Manuaba, I. G., Manuaba, C. I., \& Manuaba, F. I. (2010). Pengantar Kuliah Obstetri. Jakarta: EGC.

Mustaqeem, M., Sadullah, S., Waqar, W., Farooq, M. Z., Khan, A., \& Fraz, T. R. (2015). Obesity with Irregular Menstrual Cycle in Young Girls. Mymensingh Medical Journal, 24(1), 161-167.

National Health Service. (2016). NHS Choices. [online] Available at: https://www.nhs.uk/conditions/obesity. (Accessed: April 4, 2018).

Noviandari, I. (2016). Hubungan Antara Status Gizi dan Anemia dengan Siklus Menstruasi Pada Remaja Putri di SMA BAtik 1 Surakarta. [online] Available http://onesearch.id/Record/IOS2728.44689. (Accessed: September 2, 2017).

Rachmawati, P. A., \& Murbawani, E. A. (2015). Hubungan Asupan Gizi, Aktivitas Fisik, Persentase Lemak Tubuh dengan Gangguan Siklus Menstruasi pada Penari.[online] Available at: 
http://onesearch.id/Record/IOS2852.45791?wid get $=1$.

(Accessed: September 2, 2017).

Rakhmawati, A., \& Fithra, D. F. (2013). Hubungan Obesitas dengan Kejadian Gangguan Siklus Menstruasi pada Wanita Dewasa Muda. Jurnal of Nutrion College, 2(1), 214-222.

Ranggadwipa, D. D., \& Murbawani, E. A. (2014). Hubungan Aktivitas Fisik dan Asupan Energi Terhadap Massa Lemak Tubuh dan Lingkar Pinggang pada Mahasiswa Fakultas Kedokteran Universitas Diponegoro. [online] Available at: http://eprints.undip.ac.id/44523/

(Accessed: March 18, 2018).

Rasdini, I. G. (2016). Hubungan Lingkar Pinggang dengan Kadar Kolesterol LDL Pasien Penyakit Jantung Koroner di Ruang ICCU RSUP Sanglah Bali. Jurnal Kesehatan, VII(1), 46-51. [online] Available at: $\underline{\text { https://www.poltekkes- }}$ tjk.ac.id/ejurnal/index.php/】K/article/view/117 $\angle 103$.

(Accessed: January 2, 2018).

Rizki, N. (2015). Hubungan Status Gizi dengan Siklus Menstruasi pada Remaja Putri Kelas XI di SMK N 4 Yogyakarta.Dissertation. Yogyakarta: Sekolah Tinggi Ilmu Kesehatan 'Aisyiyah.

Santoso, B. (2014). Sindroma Ovarium Polikistik: Problem Reproduksi dan Tantangannya Terkait dengan Gaya Hidup Perempuan Indonesia. Surabaya: Universitas Airlangga.
Seif, M. W., Diamond, K., \& Nickkhoo-Amiry, M. (2014). Obesity and Menstrual Disorders. Best Practice and Research Clinical Obstetrics and Gynaecology, 516-527. HYPERLINK "https://doi.org/10.1016/j.bpobgyn.2014.10.010 " \t "_blank" \o "Persistent link using digital object identifier" doi: 10.1016/j.bpobgyn.2014.10.010

Song, J.-Y., Kim, M.-H., Paik, J.-S., Kim, H.-S., \& Na, K.-S. (2016). Association Between Menstrual Irregularity and Dry Eye Dieses: A PopulationBased study. Cornea, XXXV(2), 193-198.doi: 10.1097/ICO.0000000000000941.

Welch, C. (2011). Balance Your Hormones, Balance Your Life. Jakarta: Penebar Plus.

West, S., Lashen, H., Bloigu, A., Franks, S., Puuka, K., Ruokonen, A., . . . Papunen, L. M. (2014). Irregular Menstruation and Hyperandrogenaemia in Adolescence are Associated with Polycystic Ovary Syndrome and Infertility in Later Life: Northern Finland Birth Cohort 1986 Study. Human Reproduction, 29(10), 2339-2351.doi: 10.1093/humrep/deu200

Yani, N. G. (2016). Hubungan Aktivitas Fisik dengan Siklus Menstruasi pada Atlet Kontingen PON XIX Jawa Barat di KONI Sulawesi Selatan. [online] Available at: CORE:https://core.ac.uk/download/pdf/776268 35.pdf

(Accessed: $\quad$ September $2, \quad 2017)$. 